\title{
Comparative Analysis of Monetary Policy Shocks and Exchange Rate Fluctuations in Nigeria and South
} Africa

\author{
Sulaiman L. A. ${ }^{1}$, Lawal, N. A. ${ }^{2}$, Migiro, S. $0 .{ }^{1}$ \\ ${ }^{1}$ University of Kwazulu-Natal, Durban, South Africa \\ ${ }^{2}$ Ekiti State University, Ado-Ekiti, Nigeria \\ Sulaimanluq01@gmail.com, bodiatic@gmail.com, migiro@ukzn.ac.za
}

\begin{abstract}
The study examined a comparative analysis of monetary policy shocks and exchange rate fluctuations based on evidence from the two largest economies in Africa (Nigeria and South Africa) - from 1985 to 2015. Data were derived from various sources which include the National Bureau of Statistics, the Central Banks reports and the World Bank database. Vector Autoregressive (VAR) Analysis was used as the estimation technique. The results indicated that the foreign interest rate in South Africa had higher variations in the short-run. While in the long-run, foreign interest rate has higher percentage variations to exchange rate. In Nigeria the world oil price has the higher influence on exchange rate both in the short-run and longrun periods. Based on these results, the study then recommended that the monetary authorities and policymakers in both countries encourage external currency inflows into the economy.
\end{abstract}

Keywords: Exchange Rate, Monetary Policy, Vector Autoregressive, Nigeria, South Africa

\section{Introduction}

There is general consensus that domestic price fluctuation undermines the role of money as a store of value, and frustrates investments and growth. In the move towards stabilization and growth, countries - especially African federations shifted their attention to monetary union and exchange-rate regimes. As a monetary instrument, exchange rate movement is a concern for investors, analysts, managers, governments and policymakers due to its fluctuations Atsin (2010). According to Sulaiman (2006), monetary policy deals with inducing the availability and cost of credit to the economy with a view towards achieving the macro-economic goals of the nation. However, Simeon-Oke and Aribisala (2010)viewed that exchange rate is the price of one currency in terms of another currency. This rate is an exceptional price which government is interested in. The exchange rate of an economy has a crucial role to play, as it directly affects all the macroeconomic variables like domestic price indicator, profitability of traded goods and services, and allocation of resources and investment decisions which explains why the monetary authorities and private sector seek stability in these variables Ajakaiye (2001). The exchange rate is also seen as an essential macroeconomic variable which helps with the formulation of economic policies and reforming programs in which these policies accelerate the achievement of set macroeconomic goals. These goals include achieving and uploading price stability, the balance of payment equilibrium, full employment, even distribution of income, economic growth, and development.

Monetary variables and exchange rate are seen as macroeconomic variables that contribute to the growth and development of an economy. Monetary policy managers have paid collective attention to exchange rate instability and monetary policy shocks in the pasts. Despite manipulations by monetary authorities in terms of stabilizing the exchange rate fluctuation and the shocks on the monetary variables, there has been no consensus on the outcome. Empirical research on this has been concerned, especially on the monetary policy shocks and exchange rate fluctuations. This study undertakes a comparative analysis of monetary policy variables and the exchange rate in Nigeria and South Africa. The remaining part of the paper is structured as follows: section II reviews the literature; the method of analysis is presented in section III; results and discussion are presented in section IV; while summary, conclusion and recommendations are made in section V.

\section{Literature Review}

Monetary Policy: Nnanna (2001) opines monetary policy refers to a combination of measures designed to regulate the value, supply and cost of money in an economy - in consonance with the expected level of economic activity. Shaw (1973) expresses monetary policy as "any conscious action undertaken by the 
monetary authorities to change the quantity, availability or cost of money." Monetary policy is a method of economic management that stimulates economic growth and economic development by using its instruments, and can either be expansionary or restrictive. An expansionary monetary policy aims to sustain the growth of aggregate demand through an increase in the rate of money supply and lowering interest rates, while restrictive monetary policy is designed to reduce money supply and increase interest rates. Monetary policy targets to control money supply in order to ameliorate the various economic problems which include balance of payment (BOP) imbalances, inflation and unemployment etc (Gbosi, 2002). Thus, macroeconomic objectives like sustainability in the growth of the economy, stability in price level, BOP equilibrium along with full employment can be achieved through monetary policy by the monetary authorities. Monetary authorities are responsible for using monetary policy to grow their economies.

Exchange Rate: Exchange rate is defined as the rate at which one country's currency can be exchanged for another, and thus it is the price of one currency in terms of another (Anyawu \& Oaikhena, 1995). Exchange rate measures the value of a nation's currency against other countries' currency and reflects the economic situation of the country compared to other countries. In an open economy, the exchange rate is an important variable due to its interaction with other internal and external variables. Domestic and foreign economic policies as well as economic development greatly affect the exchange rate. In addition, the exchange rate is a variable that affects the economic performance of the country. It is an economic indicator (Havva, Mohammad \& Teimour, 2012). The importance of the exchange rate is derived from the fact that it connects the price system of two different currencies making it possible for international traders to make a direct comparison of the prices of traded goods. The exchange rate can be bilateral or multilateral. A bilateral exchange rate is described as the exchange rate of one currency like the Nigerian Naira, in terms of another, for example the US dollar (USD). On the other hand, a multilateral exchange rate also referred to as the nominal exchange rate - is the rate of one currency against a weighted composite basket of the currencies of that country's trading partners.

Empirical Literature: Mehmet and Zekeriya (2013) investigated monetary policy shocks and macroeconomic variable evidence from fast-growing emerging economies. The study used Vector Autoregressive (VAR) Analysis as an estimation technique. The results showed that a contractionary monetary policy appreciates the domestic currency, increases interest rates, effectively controls inflation rates, and reduces output. The study did not find any evidence of the price, output, exchange rate and trade puzzles that are usually found in VAR studies. It was also found that the exchange rate was the only transmission mechanism in developed countries. Zandweghe (2015) examined the relationship between monetary policy shocks and aggregate supply in the United Kingdom between 1970 and 2014. The VAR method was employed as an estimation technique. The result showed that accommodative productivity or loose monetary policy shocks temporarily boost labor by increasing work effort and the work week of capital. This study is country-specific, however, and omitted some important variables. Anzuici, Marco and Patrizio (2013) investigated the empirical relationship between monetary policy and commodity prices in the USA by means of a standard VAR model. The results suggested that expansionary US monetary policy shocks drove up the broad commodity price index and all of its components.

Alain (2007) examined the effect of monetary policy shocks on the Philippine economy. VAR was employed and the results of the monetary shock impulse responses showed that the inflation rate, world oil price, and narrow money supply significantly impacted on the Philippine economy. Asad, Ahmad and Hussain (2012) studied the impact of the real effective exchange rate on inflation in Pakistan using the time-series data of real GDP, nominal GDP, real effective exchange rate, prices and money supply - for the period 1973 to 2007. The findings showed that the real effective exchange rate had an impact on inflation in Pakistan and that a positive and significant relationship was found between the real effective exchange rate and inflation. Paul and Muazu (2016) investigated causes and effects of exchange-rate volatility on economic growth in Ghana using ARCH, GARCH and VECM. The results showed that shocks to the exchange rate are mean reverting with painful consequences in the short run. It was also found that almost three-quarters of shocks to the real exchange rate are self-driven, while the remaining one-quarter is attributed to factors like government expenditure and money-supply growth, terms of trade, and output shocks. Furthermore, excessive volatility was found to be detrimental to economic growth - however, only up to a point, as a growth-enhancing effect can also emanate from innovation and more efficient resource allocation. 
Babatunde and Olufemi (2014) studied monetary policy shocks and exchange-rate volatility in Nigeria from 1980-2009. In the study, the classical ordinary least square and Error correlation models were employed. The results showed that both real and nominal exchange rates in Nigeria have been unstable. It was equally found that the variation in the monetary-policy variable explains the movement of the exchange rate through a selfcorrecting mechanism process - with little or no intervention from the monetary authority. Results from the causality tests showed that there is a causal link between the past values of monetary-policy variables and the exchange rate. Ade and Philip, (2014) examined exchange-rate fluctuations and microeconomic performance in sub-Saharan Africa, and employed a dynamic panel co-integration analysis. The tentative results showed that a long-run relationship and a bidirectional relationship existed between exchange-rate volatility and macroeconomic performance. Muhammad and Eatzaz (2009) examined the relationship between monetary variables and nominal exchange rates in Pakistan. Generalized Method of Moments (GMM) estimates provide considerate support for the flexible price monetary model on the basis of country-by-country analysis. Therefore, the study concludes that monetary variables confirmed results for the determination of nominal exchange rates and validated monetary models as long-run equilibrium conditions.

Ncube and Ndou (2013) investigated contractionary monetary policy and exchange rate shock on the South African trade balance by using a structural vector regressive model - specifically the recursive and sign restrictive SVAR models. The interest rate was used as a monetary variable among other variables. The findings showed that the real effect of exchange-rate appreciation and contractionary monetary policy worsened the trade balance as a percentage of GDP in the long-run periods. The shock of the exchange rate on trade balance was greater than contractionary monetary policy shocks. The contractionary monetary policy operated in the expenditure-switching channel rather than the income channel in the short-run - which deteriorated the trade balance. Annari and Renee (2012) examined monetary policy and inflation in South Africa: a VECM augmented with foreign variables. The study employed co-integrated vector autoregressive (VAR) model. The study discovered three significant long-run economic relations: the augmented purchasing power parity, the uncovered interest parity, and the Fisher parity. These long-run relations were imposed on the VECM to investigate the effect of a monetary-policy shock on inflation. The results suggested an effective functioning of the monetary-transmission mechanism in South Africa. From the above literature review, it is clear that there are inconsistencies in the findings of many studies; some variables are omitted in some studies which gave room for further study and also to extend the study period covered by previous researchers. This study is also comparative, thereby providing better insight than the country-specific studies.

\section{Methodology}

Model Specification and Estimation Technique: In order to arrive at the model of this study, theoretical and empirical specifications of past researchers were considered. The modified model is in line with Fatai and Akinbobola (2015) and Babatunde and Olufemi (2014).The following variables: exchange rate, money supply, interest rate, foreign interest rate, world oil price and Consumer Price Index were used in the study. The econometric forms of the variables were presented in vector autoregressive estimation below

Vector Autoregressive (VAR): In this research, the VAR model was employed. Sims (1980)opined that, if there is simultaneity among a number of variables, then all these variables should be treated in the same way. In other words, these should be no distinction between endogenous and exogenous variables.

$$
\begin{aligned}
& E X R_{t}=\beta_{0}+\beta_{1} M 2_{t-1}+\beta_{2} I N T_{t-1}+\beta_{3} F I R_{t-1}+\beta_{4} W O P_{t-1}+\beta_{5} C P I_{t-1}+\sum E X R_{t-1-} 1 \\
& M 2_{t}=\mu_{0}+\mu_{1} E X R_{t-1}+\mu_{2} I N T_{t-1}+\mu_{3} F I R_{t-1}+\mu_{4} W O P_{t-1}+\mu_{5} C P I_{t-1}+\sum M 2_{t-1-} \\
& I N T_{t}=\theta_{0}+\theta_{1} E X R_{t-1}+\theta_{2} M 2_{t-1}+\theta_{3} F I R_{t-1}+\theta_{4} W O P_{t-1}+\theta_{5} C P I_{t-1}+\sum I N T_{t-1-} 3 \\
& F I R_{t}=\gamma_{0}+\gamma_{1} E X R_{t-1}+\gamma_{2} M 2_{i t-1}+\gamma_{3} I N T_{t-1}+\gamma_{4} W O P_{t-1}+\gamma_{5} C P I_{t-1}+\sum F I R_{i t-1}-5 \\
& W O P_{t}=k_{0}+k_{1} E X R_{t-1}+k_{2} M 2_{t-1}+k_{3} I N T_{t-1}+k_{4} F I R_{t-1}+k_{5} C P I_{t-1} \sum W O P_{t-1-1}{ }^{5} \\
& C P I_{t}=k_{0}+k_{1} E X R_{t-1}+k_{2} M 2_{t-1}+k_{3} I N T_{t-1}+k_{4} F I R_{t-1}+k_{5} W O P_{t-1} \sum C P I_{t-1-}-6
\end{aligned}
$$

Where:

EXR represents Exchange Rate;

M2 represents Money Supply;

INT represent Interest Rate;

FIR represents Foreign Interest Rate; 
WOP represents World Oil Price; and CPI represents Consumer Price Index.

Data Sources: Secondary data was employed. The data were obtained from the Central Bank of Nigeria (CBN) Statistical Bulletin, Central Bank of Nigeria Annual Reports, Economic and Financial Data for South Africa, the Global Open Data Index and from the database of the World Development Indicator (WDI). The data from this source spanned the period of 1985 to2015 - as stated in the scope of this study.

\section{Findings and Interpretation}

Figure1: Internal Monetary Variable Response to Exchange Rate: Nigeria Experience

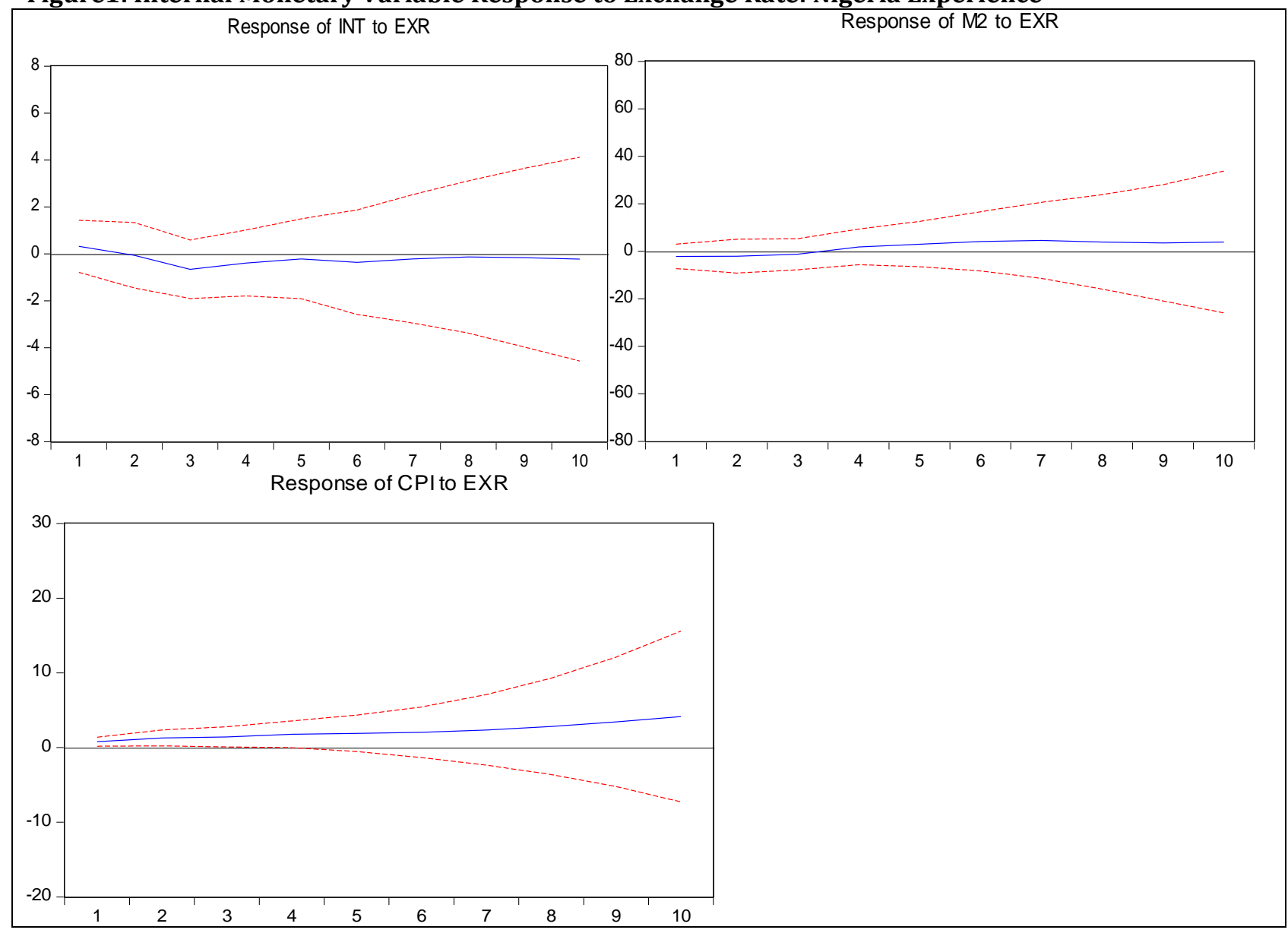

Source: Eviews 9.0

Vector Autoregressive (VAR) Impulse Response Analysis (Nigeria Experience): Impulse response function identifies the responsiveness to one standard deviation in an exogenous variable relative to one of the innovations of the endogenous variables of a model. Furthermore, it is used to predict the response of each endogenous variable to changes in other exogenous variables (Ogunsakin, 2011). Result of impulse response function is therefore presented. The result in figure 1 revealed the response of exchange rate to the shock coming from an interest rate as an internal monetary variable in Nigeria is positive from the beginning and is closer to zero in quarter two, after which it becomes negative and statistically insignificant. The economic implication of this finding stems from the fact that this result is in line with the theoretical prediction. Looking critically at the results in figure 1, the result equally confirms that a standard-deviation shock coming from the money supply inflicts negative from the beginning to the quarter of period three after which it becomes positive and has an insignificant effect on exchange rate. This equally conforms to the theoretical prediction. The response of exchange rate to the shock from the CPI, as shown in figure 1, is 
positive and statistically significant. The CPI was initially insignificant from quarter one up to quarter twobut is later significant. The economic implication of this finding is that the CPI increases, corresponding to an increase in exchange rate. However, it is not considered to be a good indicator of economic growth and price stability in Nigeria during the study period.

Figure 2: External Monetary Variables' Response to Exchange Rate: Nigeria Experience

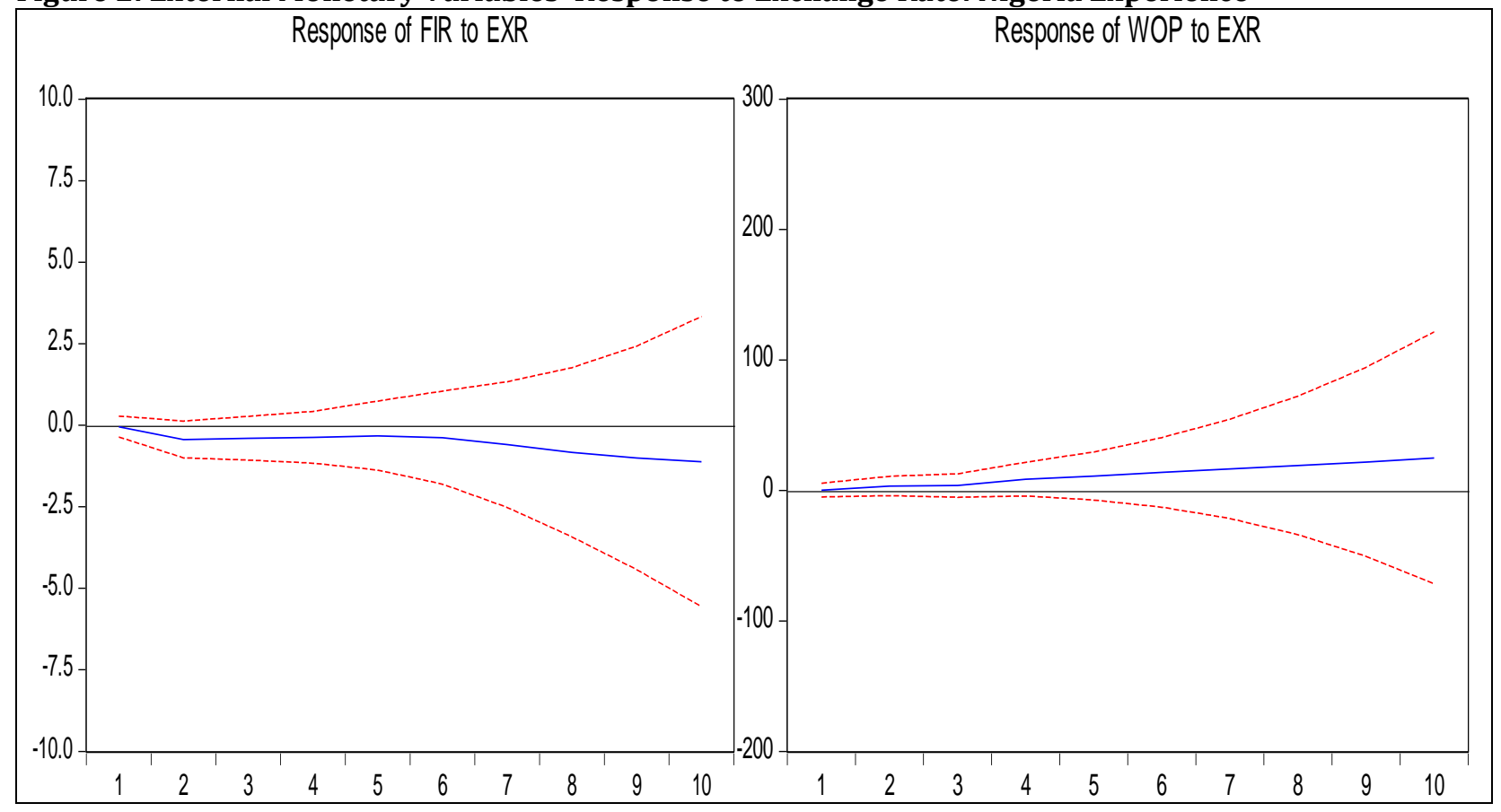

The result in figure 2 showed the external monetary variables' shock relative to exchange rate in Nigeria that is, a standard-deviation shock from a foreign interest rate has a negative but statistically insignificant impact on exchange rate in Nigeria during the study period. This finding actually conforms to the a priori expectation. According to this theoretical prediction, an unexpected foreign interest rate shock has no impact on the exchange rate. The response of the exchange rate to the shock from the world oil price is positive and significant. The economic implication of this is that an increase in the world oil price attracts more foreign currencies and strengthened the Naira.

Variance Decomposition: The result in Table 1 showed the variance decomposition of exchange rate to both the internal and external monetary variables in Nigeria during the study period. In the short-run, apart from the own shock, the world oil price has the highest percentage (31\%) of variance in the exchange-rate decision in Nigeria. This is followed by foreign interest rate that accounts for $11 \%$ of the variation to exchange-rate decision in Nigeria during the study period. Furthermore, interest rate and CPI are equally responsible for a $6 \%$ and $5 \%$ variation in the exchange-rate decision in Nigeria, while in the long run, world oil price accounts for $53 \%$ of variations, foreign interest rate for $20 \%$ of variations and money supply for $9 \%$ of variations in the exchange rate. Interest rate and CPI are insignificant in the long-run - accounting for $4 \%$ and $3 \%$ of the variations, respectively, in the exchange-rate decisions in Nigeria during the study period. This is similar to the work of Babatunde and Olufemi (2014) that the variation in the monetary policy variable explains the movement of the exchange rate. 
Table1: Variance Decomposition of Exchange Rate to both Internal and External Monetary Variables (Nigeria Experience)

\begin{tabular}{|c|c|c|c|c|c|c|c|}
\hline \multicolumn{8}{|c|}{ Variance Decomposition of EXR: } \\
\hline Period & S.E. & EXR & INT & M2 & FIR & WOP & CPI \\
\hline 1 & 10.19895 & 100.0000 & 0.000000 & 0.000000 & 0.000000 & 0.000000 & 0.000000 \\
\hline 2 & 14.77457 & 66.82903 & 7.640594 & 1.065286 & 5.412023 & 17.04005 & 2.013027 \\
\hline 3 & 19.09211 & 47.35821 & 5.649893 & 0.900267 & 10.51792 & 30.70020 & 4.873521 \\
\hline 4 & 24.06741 & 32.02881 & 6.883825 & 0.588635 & 15.61292 & 41.11029 & 3.775523 \\
\hline 5 & 31.59246 & 18.59954 & 7.168126 & 0.474669 & 20.26370 & 50.54277 & 2.951195 \\
\hline 6 & 40.88997 & 11.83419 & 7.648107 & 1.255854 & 22.81572 & 53.96275 & 2.483374 \\
\hline 7 & 52.42101 & 8.959610 & 7.039604 & 3.115560 & 23.55294 & 55.03555 & 2.296743 \\
\hline 8 & 66.58060 & 8.372872 & 6.008156 & 5.309294 & 22.85258 & 55.04665 & 2.410451 \\
\hline 9 & 83.24225 & 8.907031 & 5.191035 & 7.345302 & 21.57037 & 54.34717 & 2.639093 \\
\hline 10 & 102.2590 & 10.00969 & 4.580178 & 9.109791 & 20.16174 & 53.23363 & 2.904967 \\
\hline
\end{tabular}

Source: Authors' computation (2017)

Figure 3: Internal Monetary Variables' Response to Exchange Rate: South African Experience

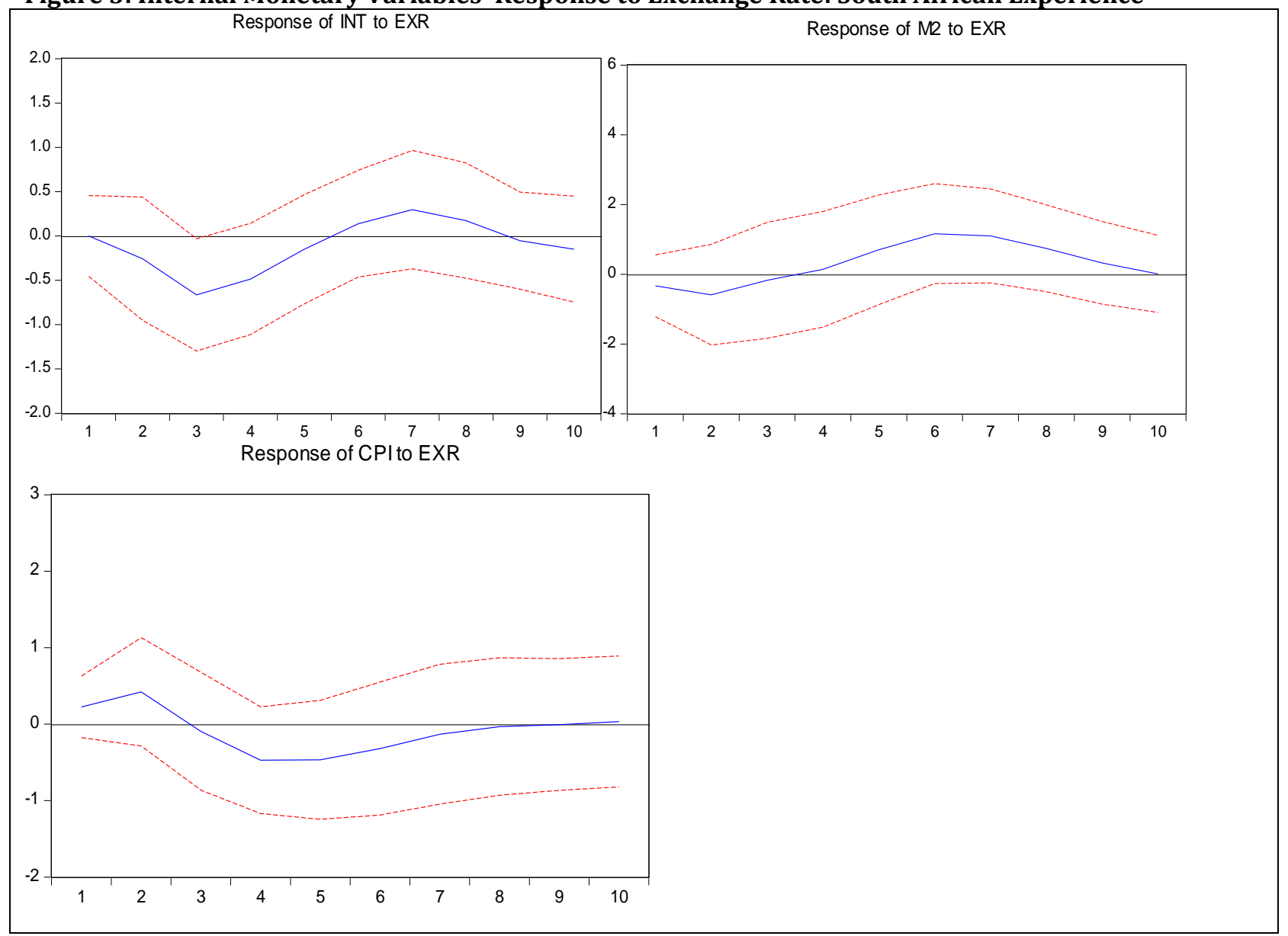

Source: Eviews 9.0

Vector Autoregressive (VAR) Impulse Response Analysis(South African Experience): The responses of South African internal monetary variables to exchange rate are presented in figure 3 showed that the standard-deviation shock of interest rate to the exchange rate displayed negative from quarter one to quarter five, and later oscillated to equilibrium at the end of quarter five, which became positive up to quarter eight, and began to decline negatively from quarters nine to ten. The implication is that the interest rate contributed both positive and negative movement to the exchange rate of South Africa during the study period. The 
shocks from money supply to exchange rate depicts negative impact from quarter one to the end of quarter three, and then oscillated from the end of quarter three in a positive upward movement, and later declined from quarter seven. The internal CPI impulse to exchange rate is positive from quarter one to quarter three and declined negatively for a long period up to quarter nine - as shown in figure 3.

Figure 4: External Monetary Variables' Response to Exchange Rate: South African Experience

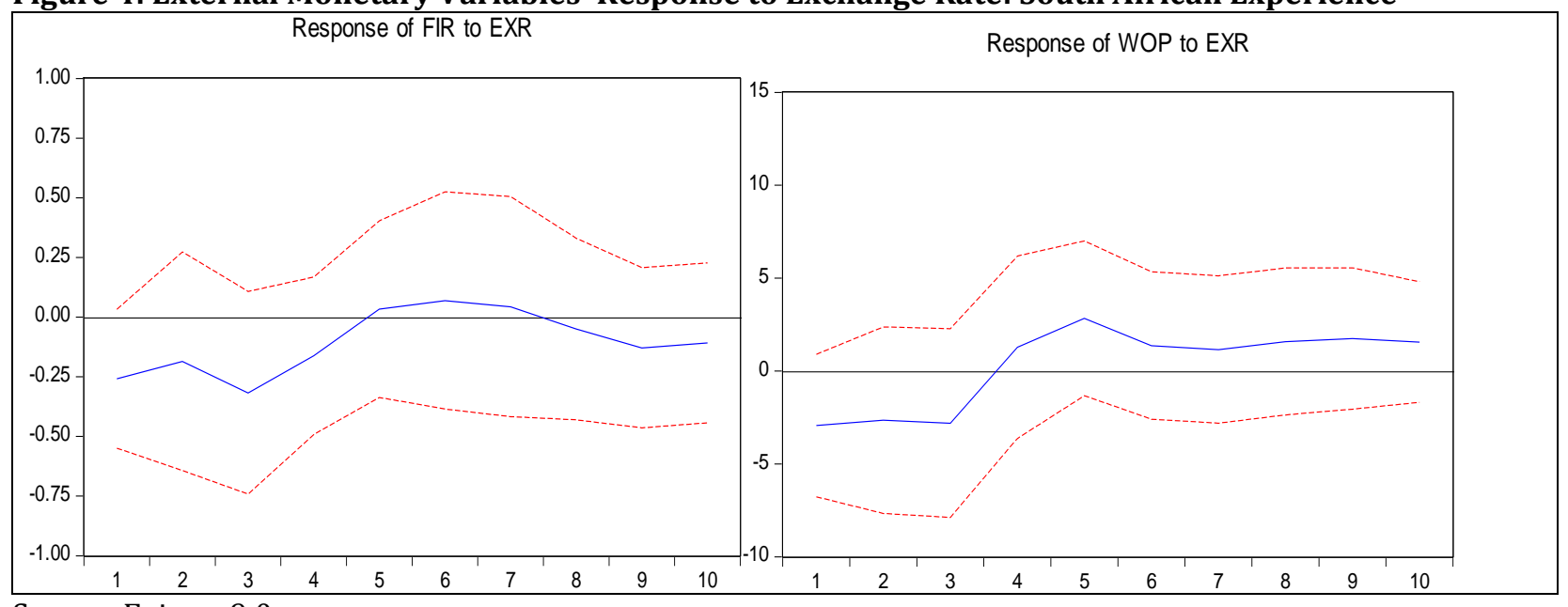

Source: Eviews 9.0

Figure 4 presented the external monetary variables such as foreign interest rate (FIR) and world oil price (WOP) deviations to exchange rate in South Africa. FIR standard deviation to exchange rate displayed negative at the beginning of quarter one to the early period of quarter five, then moved slightly positive to quarter eight, and later become negative during the study period. The innovation of world oil price to exchange rate was equally negative from quarter one to the end of quarter three, and which later becomes positive for a long period.

Table 2: Variance Decomposition of Exchange Rate to both Internal and External Monetary Variables (South African Experience)

\begin{tabular}{|c|c|c|c|c|c|c|c|}
\hline \multicolumn{8}{|c|}{ Variance Decomposition of EXR: } \\
\hline Period & S.E. & EXR & INT & M2 & FIR & WOP & CPI \\
\hline 1 & 0.699882 & 100.0000 & 0.000000 & 0.000000 & 0.000000 & 0.000000 & 0.000000 \\
\hline 2 & 0.816953 & 92.53086 & 2.060321 & 1.691963 & 0.000961 & 2.166514 & 1.549377 \\
\hline 3 & 1.015057 & 60.24333 & 9.620399 & 9.710632 & 14.42054 & 3.850169 & 2.154933 \\
\hline 4 & 1.116511 & 50.35770 & 11.77301 & 8.042135 & 24.65970 & 3.337064 & 1.830390 \\
\hline 5 & 1.140234 & 49.14838 & 11.31041 & 8.121554 & 24.28023 & 3.224676 & 3.914761 \\
\hline 6 & 1.210018 & 43.90796 & 13.70538 & 8.010205 & 24.10381 & 3.754758 & 6.517890 \\
\hline 7 & 1.333268 & 36.35991 & 17.08134 & 9.573141 & 25.69135 & 4.031354 & 7.262901 \\
\hline 8 & 1.440421 & 32.13672 & 18.43376 & 11.06706 & 26.57523 & 4.134054 & 7.653182 \\
\hline 9 & 1.506760 & 30.69762 & 18.44839 & 10.95274 & 27.11435 & 4.373150 & 8.413747 \\
\hline 10 & 1.548242 & 30.02874 & 18.10585 & 10.38856 & 27.73617 & 4.697809 & 9.042870 \\
\hline
\end{tabular}

Source: Authors' computation (2017)

Variances' Decomposition (South African Experience): Table 2 (above) shows the variance decomposition of exchange rate to both the internal and external monetary variables utilized in the South African economy during the study period. In the short-run, apart from the own shock that is exchange rate, the foreign interest rate has the highest percentage $(14.4 \%)$ of variance in the exchange-rate decision in South Africa. This is followed by money supply and interest rate which account for $9.7 \%$ and $9.6 \%$ of variations respectively in the exchange-rate decision in South Africa during the study period. Also, world oil price and CPI are equally responsible for a $3.9 \%$ and $2.2 \%$ variation in exchange-rate decision in South Africa during the study period. In the long-run, the foreign interest rate accounts for $28 \%$ of variations, interest rate for $18 \%$ of variations, 
and money supplyfor $10 \%$ of variations in the exchange rate. CPI accounts for $9 \%$ of variations in the exchange rate. World oil price is insignificant in the long-run - with only a 5\% impact on the exchange-rate decision in South Africa during the study period.

Summary: This study focused on a comparative analysis of monetary policy shock and exchange rates in the two largest economies in Africa (Nigeria and South Africa). The rationale for this analysis was due to the realization that fluctuations in exchange rate through internal and external monetary policy innovations, took place in both Nigeria and South Africa. Based on the analysis, the South African foreign interest rate has higher variations in the short-run. This was followed by money supply and interest rate. The world oil price and CPI have lower variations in the short-run. In the long-run, the South Africa Rand in terms of other currencies shows that foreign interest rate equally has the higher percentage of variations to exchange rate, followed by interest rate and money supply - while CPI and world oil price have the lowest variations in exchange-rate fluctuations. The Nigerian analysis revealed that world oil price has the higher percentage of variations in exchange rate in the short-run, followed by foreign interest rate and interest rate - while CPI and money supply have lower variations to exchange rate in the short-run. In the long-run, world oil price also has the highest percentage influence on exchange rate, followed by foreign interest rate and money supply. Domestic interest rate and CPI had a lower variation to exchange rate in Nigeria during the study period.

\section{Conclusion and Recommendations}

The aim of this study is to make a comparative analysis of monetary policy shock and exchange-rate fluctuations, based on evidence from the two largest economies in Africa (Nigeria and South Africa). This study concluded that the external monetary variables employed in the study - world oil price and foreign interest rate contributed more impacts compared to internal monetary variables like money supply, interest rate and CPI. In South Africa, foreign interest rate acquired a higher percentage variation to influence exchange rate during the study period, while in Nigeria world oil price acquired a higher percentage of variations in exchange rate during the study period. Simultaneously, foreign interest rate equally controls higher variations in the long-run with the South Africa experience, while world oil price controls higher variations as far as Nigeria is concerned. It also concluded that Nigeria is a crude-oil exporting country which contributes largely to exchange-rate fluctuations - implies that the higher the cost per barrel of crude oil, the more foreign currencies Nigeria earns. However, South Africa is not a crude-oil exporting country and is rather an importing country. Furthermore, foreign interest rate contributes moderately in both countries in terms of exchange-rate fluctuations. The internal monetary variables equally contribute to exchange rate but not significantly to influence the fluctuations in exchange rate. From the findings, it is therefore suggested that the monetary authorities and policy-makers in the two countries should encourage external currency flows of foreign interest rate and world oil price into the economy. It is equally suggested that the internal monetary variable particularly interest rate and consumer price index should be strengthened in order to avoid sudden movement of the country's currency in term of other currencies.

\section{References}

Ade, T. O. \& Philip, O. A. (2014). Exchange rate fluctuations and microeconomic performance in Sub-Saharan Africa: A dynamic panel co-integration analysis. Asian Economic and Financial Review, 4(11), 1573159.

Ajakaiye, O. (2001). Economic development in Nigeria: A review of recent experience: Proceedings of the First Annual Monetary Policy Conference, Central Bank of Nigeria.

Alain, K. (2007). Effect of monetary policy shocks to the Philippine economy. A vector auto regressive (VAR) approach. National Convention on Statistics (NCS), EPSA Shangri-la Hotel.

Annari, D. W. \& Renee, V. D. (2012). Monetary policy and inflation in South Africa: A VECM augmented with $\begin{array}{lllll}\text { foreign } & \text { variables. } & \text { ERSA } & \text { working }\end{array}$ http://ecorsa.org/home/index.php?option=com_doman\&gid=download\&gid=494Itemid=67.

Anyawu, J. C. \& Oaikhena, H. E. (1995). Modern macroeconomic theory of appreciation in Nigeria. Onitsha: Joane Educational Publishers Ltd. 
Anzuici, A., Marco, J. L. \& Patrizio, P. (2013). The impact of monetary policy shocks on commodity prices. International Journal of Central Bank, 9(3), 119-141.

Asad, I., Ahmad, N. \& Hussain, Z. (2012). Impact of real effective exchange rate on inflation in Pakistan. Asian Economic and Financial Review, 2(8), 983-990.

Atsin, S. B. (2010). Firm-level responses to monetary union and exchange rate regime: Evidence from Cote D'ivoire and Ghana. http://www.westminster.ac.uk/research/westminsterresearch

Babatunde, W. A. \& Olufemi, M. S. (2014). Monetary policy shock and exchange rate volatility in Nigeria. Asian Economic Review, 4(4), 544-562

Simeon-Oke, O. O. \& Aribisala, S. E. (2010). Exchange rate Deregulation and Industrial Performance: An Assessment. An International Multi-Disciplinary Journal, 4(2), 236-251.

Fatai, M. O. \& Akinbobola, T. O. (2015). Exchange rate pass-through to import prices, inflation and monetary policy in Nigeria. International Finance and Banking, 2(1),60-78.

Gbosi, A. N. (2002). Financial sector instability and challenges to Nigeria's monetary authorities. Port Harcourt: African Heritage Publishers.

Havva, M. T., Mohammad, R. M. \& Teimour, M. (2012). Effect of the Real Effective Exchange Rate Fluctuations on Macro-Economic Indicators. Interdisciplinary Journal of Contemporary Research in Business, 4(6), 1097-1103.

Mehmet, I. \& Zekeriya, Y. (2013). Monetary policy shocks and macroeconomics variables: Evidence from fast growing emerging economies. Discussion paper No 2013-61. http://www.economicsejournal.org/economics/discusion papers/2013-61

Muhammad, Z. \& Eatzaz, A. (2009). Testing the monetary models of exchange rate determination: Some new evidence from modern float. Chulalong korn Journal of Economics, 21(3), 125-145.

Ncube, M. \& Ndou, E. (2013). Monetary Policy and Exchange Rate Shocks on South African Trade Balance, Working Paper Series $N^{\circ} 169$ African Development Bank, Tunis, Tunisia.

Nnanna, O. (2001). The monetary policy framework in Africa: The Nigerian experience. Extracted from: www2.resbank.co.za/internet/publication..../Nigeria.pdf, p. 11.

Ogunsakin, S. (2011). Intermediate monetary economics. Ado-Ekiti: Jossy Kay Printers.

Paul, A. \& Muazu, I. (2016). On the causes and effect of exchange rate volatility on economic growth: Evidence from Ghana. International Growth Centre. www.theigc.org

Shaw, E. (1973). Financial deepening in economic development. New York: Oxford University Press.

Sims, C. A. (1980). Macroeconomics and reality. Econometrica, 48(1), 1-48.

South African Reserve Bank. (2016). Monetary policy review. South Africa. www.reservebank,co.za

Sulaiman, L. A. (2006). Conceptual issues in monetary and fiscal policies management. Ondo: Adeyemo Publishing House.

Zandweghe, V. W. (2015). Monetary policy shocks and aggregate supply. Economic Review, Q III, 1-56. 